\title{
REVIEW ARTICLE: BEYOND THE POLIS? NEW APPROACHES TO GREEK RELIGION
}

\author{
Thomas Harrison
}

University of St Andrews

Abstract

This article reviews a range of important recent work on Greek religion. It looks first at the critique (common to a number of the books under review) of the polis-religion model associated with Christiane Sourvinou-Inwood, and then attempts to draw out a number of emerging themes: a comparative approach, a focus on the gods or on individual worshippers, and a cognitive perspective. It then examines in more detail the application of the terms 'belief' or 'theology' to the field of Greek religion, and the extent to which any picture of Greek religious experience may be said to be logically coherent, before looking forward to possible future directions of study.

\section{Keywords}

Polis-religion, belief, theology, ritual, inconsistency

BEERDEN (K.) Worlds full of signs : ancient Greek divination in context. Leiden, Boston: Brill, 2013 (Religions in the Graeco-Roman world vol. 176). Pp. $248+$ xi. €109.00. 9004252398 (hbk.). JIM (T.S.F.) Sharing with the Gods. Aparchai and Dekatai in Ancient Greece. Oxford: Oxford University Press (Oxford Classical Monographs). Pp. $373+$ xv. £80. 9708198706823

KINDT (J.) Rethinking Greek Religion. Cambridge: Cambridge University Press, 2012. Pp. 235 + xiii. f20.99. 9780521127738 .

NAIDEN (F.S.) Smoke Signals for the Gods. Ancient Greek Sacrifice from the Archaic through Roman Periods. New York: Oxford University Press, 2013. Pp. $421+$ xiii. $£ 45.9780199916405$. PARKER (R.) On Greek Religion (Cornell Studies in Classical Philology 60). Ithaca and London: Cornell University Press, 2011. Pp. xv + 309. £49.50 (hbk); £19.95 (pbk). 9780801449482 (hbk); 9780801477355 (pbk).

POLINSKAYA (I.) A local history of Greek polytheism: gods, people and the land of Aigina, 800-400

BCE. Leiden, Boston : Brill, 2013 (Religions in the Graeco-Roman world vol. 178). Pp. $690+$ xxviii. $€ 207.00$. 9004234047 (hbk.).

tehh@st-and.ac.uk 
RICHER (N.) La religion des Spartiates : croyances et cultes dans l'Antiquité. Paris : Belles lettres, 2012. Pp. 806. €55.00. 2251381139 (pbk.).

ROSENBERGER (V.) Religion in der Antike. Darmstadt : WBG (Wissenschaftliche Buchgesellschaft), 2012. €14.90. Pp. $136+$ vii.

ROSENBERGER (V.) Divination in the Ancient World. Religious Options and the Individual. Stuttgart: Franz Steiner Verlag, 2013 (Potsdamer Altertumswissenschaftliche Beiträge vol. 46). Pp. 177. €48.00. 9783515106290.

SALZMAN (M. R), SWEENEY (M.A.), and ADLER (W.) Eds. The Cambridge History of Religions in the Ancient World (2 vols.). Cambridge: Cambridge University Press, 2013. 2 vols.: vol. 1 (ed. By M.R. Salzman and M.A. Sweeney), vol. 2 (ed. By W. Adler); pp. $450+$ xiii; $589+$ xviii). \$264.99. 1107019990. VERSNEL (H.S.) Coping with the Gods. Wayward Readings in Greek Theology. Leiden: Brill, 2011. Pp. $593+$ xiii. €215. 9789004204904. 
In a striking passage of his Practice of Everyday Life Michel de Certeau envisages belief in the modern world as a diminishing resource. Where people had once assumed that the 'reserves of belief were limitless', and the challenge was to '[capture] the energy of belief by moving it about', transferring it and investing it in 'campaigns and crusades', 'there are now too many things to believe and not enough credibility to go around'. ${ }^{1}$

Certeau's vision of the erosion of belief might perhaps raise questions for us about the causes of shifts in scholarly trends: whether our earlier focus on the psychological well-springs beneath the institution of sacrifice, our conviction in the eminently social nature of Greek religion, or our rationalising away of ancient authors' apparently pious protestations, may reflect our own inability to give credence to the theological commitments of the Greeks. (We might contrast E.R. Dodds's conviction that we should credit the apparent commitments of 'literary religion', rather than dismiss them as 'agreeable interlude[s] of lighthearted buffoonery'. ${ }^{2}$ ) For de Certeau, however, this erosion of belief is a phenomenon that refers to a much broader range of phenomena than simply religion: in the modern world, in which the wells of belief have been polluted, we have turned instead to producing belief artificially through political or commercial marketing. Certainly, to judge from the range of hugely stimulating books under review - themselves only a sample of a wider body of work that makes up a remarkable, if uncertain, renaissance in the study of Greek religion ${ }^{3}$ - belief has drained likewise out of the main tenets in the study of our subject. The traditional approaches to sacrifice of the twin giants Walter Burkert and Jean-Pierre Vernant suffer a relentless assault, as Fred Naiden seeks to put the gods back into sacrifice in his Smoke Signals to the Gods. ${ }^{4}$ Irene Polinskaya offers an alternative to the microcosmic or macrocosmic analyses of Greek religion - both, as she envisages, cul-de-sacs ${ }^{5}$ - in her detailed account of what she terms the Aeginetan 'mesocosm'. ${ }^{6}$ Belief itself - long an uncomfortable term - swaggers back in as a category in Greek religion through the final appendix of Henk Versnel's monumental Coping with the Gods. ${ }^{7}$ And finally, but not least, the

\footnotetext{
${ }^{1}$ (1984) $177-189$ at $178-9$.
}

'Dodds (1951) 18; cf. pp. 9-11, 43, 105, 117.

${ }^{3}$ In addition to those under review, see esp. Gagné (2013) or the ongoing work of Eidinow, e.g. (2007), (2011).

${ }^{4}$ Naiden (2013); see also the explorations of the historiography of sacrifice in Faraone and Naiden (2012).

${ }^{5}$ (2013) 33.

${ }^{6}$ A term (coined by the anthropologist, Robert Levy) that could cover a range of types and sizes of political organisations, from the Attic deme through the small poleis of 'multi-polis islands' to an 'island-state' like Aegina: (2013) 3, 35.

'Building on the work of Naerebout (1997), Feeney (1998), Harrison (2000) King (2003) and Wiebe (1979). 
centrality of the polis is questioned, in respect of Greek religion and more broadly, not least in Julia Kindt's richly thought-provoking Rethinking Greek Religion. ${ }^{8}$

It is now a quarter-century since the publication of the most sophisticated formulation of the model of 'polis-religion'. Similar ideas may have been expressed before, but it was with Christiane Sourvinou-Inwood's 1990 paper 'What is polis religion?' that the term became, in her friend and colleague Robert Parker's words, a 'term of art, the summation of an approach and a theory'. ${ }^{9}$ The model of polis-religion now stands besieged on all sides. On the one hand - for example, in Kindt's opening chapter - it is argued that there are aspects of religious experience that the model cannot or does not reach: personal religion, magic, or religious discourse. ${ }^{10}$ On the other hand, in her weighty account of the 'local [Aeginetan] history of Greek polytheism', Irene Polinskaya critiques the model for being underdeveloped.

There is a danger here - as always when we seek to mark out a new direction by reference to older positions - of misrepresenting or misremembering the tenor of the argument we are critiquing, or of overstating our reaction. (Naiden, the 'Burkert-slayer', indeed undermines the force of his own argument by a wearying insistence on the omissions of Burkert, Vernant and Detienne. ${ }^{11}$ ) There is a danger likewise of taking that argument out of its own polemical context. As Julia Kindt lays out sympathetically and in detail, the polis-religion model, in its Oxford and Paris variations, ${ }^{12}$ was a salutary rejoinder to previous approaches, a statement of the centrality of the polis to the organisation of religion, and vice versa, which has prompted a host of new insights, not least into the relationship of religion and power; ${ }^{13}$ and which invited detailed analyses of the religious histories of individual

\footnotetext{
${ }^{8}$ Kindt (2012), reviewed by Emily Kearns in JHS 2014, 217-8; see also Kindt (2015) for personal religion; for questioning of the polis's centrality more broadly, Vlassopoulos (2007).

${ }^{9}$ Parker (2011) 57-8.

${ }^{10} \mathrm{Cf}$. Georgoudi (2010) 92 for the criticism that sacrifice was insufficiently central.

${ }^{11}$ I say this in full acknowledgement of my own past excesses. For a balanced and sophisticated assessment of their contrasting theories, see Parker (2011) ch. 5.

${ }_{12}$ (2012) 16-17: the Oxford model putting less emphasis on the control of religious practices, seeing religion instead as 'merely mapped on to the institutional landscape of the polis'.

${ }_{13}$ Woolf (1997) 73-4; cf. Cf. Kearns' observations in the Cambridge History, Salzman, Sweeney and Adler (2013) i. 285, that the polis model 'at least draws attention to the intimate relationship between religion and the state - and also expresses what many Greeks, including Plato, felt was the ideal', or Bremmer's characterisation of Wilamowitz's assimilation of Greek religion with Christianity, (2010b) 9-10.
} 
poleis - Sparta and Aegina now, as well as Athens. ${ }^{14}$ Importantly also, even if the model overstates the extent to which all religious activity is 'encompassed' by the polis ${ }^{15}$ ('There is religion without the polis, even if there is no polis without religion', in the words of no less a figure than Burkert ${ }^{16}$ ) it always in fact gave some place both to the individual and to religious discourse - at least in so far as each was 'anchored in' or mediated by the polis. ${ }^{17}$ So, for example, Sourvinou-Inwood relied on a passage of Xenophon's Memorabilia, in which the Pythia advises enquirers that the way to act piously is to follow the nomos of the polis, in arguing that even private manifestations of religiosity were dependent on the polis. ${ }^{18}$

'Polis-religion' was never designed, as Robert Parker insists (in part responding to Kindt's first publication of her critique), to constitute a 'new paradigm in the sense of replacing existing ones', as a denial of private sacrifices, or that 'individuals went outside the confines of their city for religious purposes'. ${ }^{19}$ An alternative criticism of the polis-religion model, as articulated by Sourvinou-Inwood, would be not so much that it excluded as that it marginalised certain aspects of religious experience, prioritising one possible organising framework over and above all others; or that by bundling everything within a single 'supreme category', it does not do justice to the texture and variety of religious activity. ${ }^{20}$ As Kindt argues compellingly, there is a danger of seeing things that do not fit the polis model as 'not religion proper' (how easy is it for any of us to perform the same manoeuvre unwittingly?), and so - in circular fashion - 'marginalis[ing] exactly those areas of religious activity that the model cannot sufficiently explain'. ${ }^{21}$ Or, to put the same point in more extreme terms, it is possible - as Greg Woolf suggested in the context of the extension of the model of polis-religion to a Roman provincial context that there is a 'risk of collusion with just one view of ancient religion, that of those who controlled the polis'. ${ }^{22}$ What other perspectives are being occluded (to extend Woolf's argument) if our vantage-point is the Capitol or the Acropolis? If, as Simon Price once speculated, ${ }^{23}$ we were able to survey the views of individual Athenians or Aeginetans, how important would questions of control

\footnotetext{
${ }^{14}$ Polinskaya (2013), Richer (2012) (a fine work of synthesis, without any sustained engagement with larger theoretical issues of the definition of Greek religion), Zunino (1997); for Athens, preeminently Parker (1996), (2005).

${ }^{15}$ Sourvinou-Inwood (2000b) 51.

${ }_{16}^{16}$ Burkert (1995) 203, cited by Kindt (2012) 19; cf. Polinskaya's rejoinder to Kindt, (2013) 499-50 n. 24.

${ }^{17}$ For Sourvinou-Inwood's narrow definition of religious discourse, (2000a) 20-21; for the role of the individual, Sourvinou-Inwood (2000b) 44.

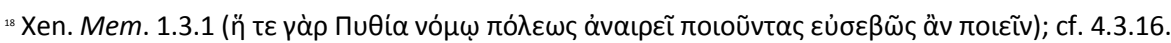

${ }^{19}$ Parker (2011) 58, endorsed by Jim (2014) 130, and substantiated in Parker (2005) e.g. chs. 2, 4.

${ }^{20}$ Eidinow (2011) 32.

${ }^{21}$ Kindt (2012) 22.

${ }^{2}$ Woolf (1997) 72.

${ }^{23}$ Price (1984) 5.
} 
or authority in fact have seemed on a day-to-day basis? Would the supervisory role exercised by the Athenian polis over the Eleusinian mysteries have been a central issue for the initiate ${ }^{24}$ - or would he or she have looked at the mysteries from the other end of the telescope, with personal anxieties or experience as central? Versnel puts it bluntly. Whereas there is evidence from across the Mediterranean of 'thousands of votive gifts and inscriptions..., generally dedicated by one or few persons ... testimonies of, in the most explicit sense, private and personal religiosity', in textbooks on Greek religion, we find instead the 'mantra-like repetition ... of the assertion that in terms of religion the individual Greek functions only as part of the polis or as part of a group within that polis' ${ }^{25}$

Whether this marginalising of other themes was an aspect of Sourvinou-Inwood's exuberant original formulation, or of its reception and elaboration by others, is perhaps unimportant. What matters more perhaps is simply that a thesis which focussed on a particular range of questions - 'about organisation, policing, control ${ }^{26}$ - came to be presented as something significantly more allencompassing, that one set of questions crowded out others. For, in seeking to distinguish Greek religion from assumed (Christianising) models of religion - a prime concern in the study of Greek religion in the 1980s and 1990s - these were the questions that were important; it was the polis that stood in for the institutional paraphernalia of a Christian church. ${ }^{27}$ The dominance of the polis went hand-in-hand also with the primacy of ritual (and the exclusion of belief); each reinforced the other. It is tempting now with hindsight to pour oil over troubled waters, to over-emphasize the actual inclusiveness of the polis-religion model, or to forget the zeal with which it was sometimes asserted. Versnel again calls a spade a spade here, referring in passing to Price's 'first crusade' against the term 'belief', and citing a whole plethora of doctrinaire quotations on the primacy of ritual. ${ }^{28}$ In our exaggerated anxiety to differentiate ancient and modern, it now seems as if we over-privileged the role of Christianity, and mistook (as Kindt argues in another context) a religion's own concepts as external, descriptive categories. ${ }^{29}$ (Certainly, new generations of students, without the same

\footnotetext{
${ }^{24}$ Cf. Sourvinou-Inwood (2000b) 54.

${ }^{25}$ Versnel (2011) 122-2: cf. the observations of Rüpke (2013) 6.

${ }^{26}$ Parker (2011) 58; cf. Rüpke (2013) 3.

${ }^{27}$ Sourvinou-Inwood (2000a) 19-20, reformulated by Kindt (2012) 16 (Greek religion 'differed from Christianity in that it had no dogma, no official creed, no Bible, no priesthood in the form of a specially trained and entitled group of people, and no church. In the absence of such powerful organising principles, religion was structured alongside the socio-political structures of the polis.') ${ }^{28}$ Versnel (2011) 5, 544-5; cf. Naiden's concluding observations on the exclusion of 'implicit beliefs', Naiden (2013) 330.

${ }^{29}$ Harrison (2000) 20, Versnel (2011) 553-4; cf. Kindt (2012) 108, 113.
} 
familiarity with organised religion as a point of reference, can seem perplexed now by modern scholars' repetition of the 'negative catechism'.$^{30}$ )

Through the starting assumption of a fundamental divide between ancient and modern, we also arguably closed ourselves off from one possibly fruitful field for comparison, paralysed with fear of importing associations alien to the object of study. ${ }^{31}$ Here there is clear evidence of a change in climate across a range of the books under review. The editors of the Cambridge History make valiant efforts, on the one hand, to ensure a sufficient uniformity of approach to allow for comparison while, on the other, not imposing similarities through inadvertent Procrusteanism. ${ }^{32}$ For the most part, they achieve that - even if, in so doing, the plural 'religions' in which their subject is parcelled out are inevitably artificial entities. $^{33}$ Kim Beerden's Worlds Full of Signs picks out the distinctive elements of Greek divination through a structured comparison with two ancient contexts (Republican Rome and Mesopotamia ${ }^{34}$ ), drawing a number of measured conclusions: that in Greece the client or 'divinans' (in her term) tended to be lower down the social scale than in her more institutionalised comparator cultures, that Greek divinatory culture was predominantly an oral one, and - most strikingly - that it presented a different temporal perspective. ${ }^{35}$ Greek divination presented a plurality of futures, like 'various roads going off in different directions [with] the client as the person standing at a crossroads, attempting to pick the best path to take'; divination offered 'a tool for revealing and exploring future possibilities'. In Mesopotamia, by contrast, the future was 'one ongoing road which, bit by bit, was

\footnotetext{
${ }^{30}$ The phrase of Garland, (1994) ix, to describe the reiteration of all the aspects of modern Christianity absent in Greek religion. The reason for this gulf might be sought in the specific religious backgrounds and commitments of modern scholars, for an assessment of which see Gough-Olaya (2014). For speculations here see also Parker (2011) vii, Versnel (2011) 552-4, Bremmer (2010a) 24 (on the influence of Sourvinou-Inwood's distinctively Orthodox background).

${ }^{31}$ Cf. Versnel (2011) 541; for Price's "obsessive fear for Christianising projections', see p. 554 n. 31 , citing reviews of Price 1999.

${ }^{32}$ Salzman, Sweeney and Adler (2013) 9.

${ }^{33}$ See observations of Rüpke, (2014) 8, 22-5. Skjaervo's account of Zoroastrianism, e.g., is fundamentally a survey of the religion of the Avesta, with a very short annexe on Achaemenid religion (Henkelman (2008) is a fundamental omission here) and on the history of scholarship. Only the last line of his account (i. 127) acknowledges in straightforward fashion that the "Gâthâs obviously did not "mean" the same in Achaemenid times as they did when they were composed'; contrast the approach to later Iranian religion by de Jong, ii. 25-7.

${ }^{34}$ On the former, see now esp. Santangelo (2013).

${ }^{35}$ Beerden (2013) 224-6 (quotation from p. 226).
} 
made known to the individual'; divination operated, in her term, as a telescope, 'used to consider a relatively distant specific point in time', and so to reduce uncertainty. ${ }^{36}$

Divination has long, in fact, been one aspect of Greek religion more susceptible to comparative approaches; ${ }^{37}$ the range of points of comparison in Beerden's monograph is relatively restricted. Other authors - Theodora Jim in her discussion of first fruits, ${ }^{38}$ or Versnel in his Coping with the Gods - are freer, less guarded, in their comparative perspective. In particular, Versnel's range of comparative reference, the harvest of an extraordinary career, ${ }^{39}$ is dizzying: from ancient Egyptian, medieval or modern Christian piety, to the insights of cognitive science, or (charmingly) the hungry robin 'who thinks he owns our garden'. ${ }^{40}$ Religion, for Versnel, is fundamentally cognitive ('Religion ... is in the mind', as he quotes from Richard Gordon ${ }^{41}$ ). And, except in so far as the Greeks 'never lost an awareness of living in a dissonant, pluralistic, diverse reality' (implicitly, unlike us), they are, very far from being 'desperately foreign', like us. ${ }^{42}$ Notwithstanding, however, Versnel's concern to uncover Greek patterns of thinking, his wariness of making explicit what was for ancient authors only 'implicit and opaque', ${ }^{43}$ he also has no qualms about using etic terminology to describe Greek culture, ${ }^{44}$ or in deploying terminology that others would consider too hot to handle. Where Robert Parker eschews the term 'miracle' in a Greek context, for example ('There is no Greek word for "miracle", and the word is absent because the concept is absent $\left.{ }^{45}\right)$, Versnel is unembarrassed in drawing out parallels and differences: 'Greek gods can work miracles' ${ }^{46}$ Likewise, in a fine discussion of the complexity of different cultural expressions of gratitude, Theodora Jim moves beyond a narrowly lexical focus: 'the ancient Greeks did not lack terms with which to denote "thank-offerings" explicitly. At the same time a community's pervasive use of the English phrase "thank you" (or its

\footnotetext{
${ }^{36}$ (2013) 226-7.

${ }^{37}$ E.g. Whittaker (1965), Parker (1985), Maurizio (1995), Eidinow (2007).

${ }^{38} \mathrm{Jim}$ (2014), e.g. 23, 90 n. 12 (on Chinese mooncakes).

${ }^{39}$ In which he was no less open to a wide range of comparison: see e.g. Versnel (1990).

${ }^{40}$ Versnel (2011) 379.

${ }^{41}$ Versnel (2011) 471 (continuing: 'It consists not so much in religious acts as in schemes of perceptions and thoughts whose meaningfulness is repeatedly reinforced by the performance of symbolic acts.')

${ }^{42}$ Versnel (2011) 149.

${ }^{43}$ Versnel (2011) 167 of E. R. Dodds.

${ }^{44}$ Versnel (2011) 548. Cf. Salzman, Sweeney and Adler (2013) i. 1, arguing that 'any effort to define religion in the ancient Mediterranean is constrained from the very outset by the absence of a single-word equivalent in the ancient languages', Polinskaya (2013) 9.

${ }^{45}$ Parker (2011) 9 (continuing: 'Instead of miracles, we have a range of unusual occurrences that may have a divine origin').

${ }^{46}$ Versnel (2011) 400-421 (quotation from p. 400).
} 
variants) need not imply that its people are more prone to feeling grateful, or vice versa. ${ }^{47}$ Laudable as is the desire to examine the Greeks (or any other historical context) 'in its own terms', purifying our language of terms for which there is no tidy equivalent in the culture under study provides no magic shortcut; ${ }^{48}$ arguably indeed it has the effect of obscuring inadvertent associations.

Another new focus in the study of Greek religion might seem surprising: a focus on the gods themselves. 'Sharing with the gods', 'coping with the Gods'...; the gods have moved centre-stage, offering (and necessitating) help, receiving 'not just [a] reciprocal exchange of goods and service' but 'goodwill, delight, and gratitude'. ${ }^{49}$ The stated ambition of Bremmer and Erskine's 2010 collection is to 'put the gods back into Greek religion', ${ }^{50}$ whereas for Naiden, conversely, the effect of the insights of Burkert, Vernant and others was to reduce the god to a 'visitor at a human occasion'. ${ }^{51}$ The central argument of Naiden's monograph is that the gods might say no, rejecting a given sacrifice - a possibility that then in turn requires determined human effort to address. ${ }^{52}$ The gods are not just ciphers, or blank screens, moreover, but personalities, a 'real and potent presence'. ${ }^{53}$ 'It is my unfashionable impression', according to Versnel, 'that in everyday religious practice individual Greek gods were practically never conceived as powers, let alone as cultural products, but were in the first palace envisaged as persons with individual characters and personalities'. ${ }^{54}$ Or, to put it another way, an emic perspective is now displacing the old 'quests for origin, function or meaning'. 55 'A broadly defined interest in the theology and religious world-view of antiquity', as Renaud Gagné remarked in his fine 2013 book on the concept of inherited guilt, ${ }^{56}$ 'is replacing the earlier insistence on ritual, function and social practice in the study of Greek religion, and the research programmes based on the promises of a cognitive grid could easily generate a shared enthusiasm not seen since the heady days

\footnotetext{
${ }^{47} \operatorname{Jim}(2014) 76-81$ at 81.

${ }^{48}$ See e.g. the rationale of the Cambridge History, Salzman, Sweeney and Adler (2013) i. 3, to seek to 'analyse ancient religions on their own terms', aware of how ancient religions might depart from modern presuppositions' (the example used is that ancient "'religious" practitioners' might not be considered 'particularly "religious"' today).

${ }^{49} \operatorname{Jim}$ (2014) 22; cf. Pulleyn (1997), Parker (1998).

${ }^{50}$ Erskine (2010) 505.

${ }^{51}$ (2013) 14. Contrast Beerden (2013) 3 (Divination is 'essentially a human act which tells us about human society'), Beckman in Salzman, Sweeney and Adler (2013) i. 97 in the context of the Hittites ('it was all about them [men and women], and in practice the gods received attention only because of their putative potential influence upon the human level of the cosmos').

${ }^{52}$ See, however, Pirenne-Delforge and Prescendi (2011) for parallel insights.

${ }^{53}$ Erskine (2010) 510; for a rich and balanced account, see esp. Parker (2011) ch. 3.

${ }^{54}$ Versnel (2011) 317.

${ }^{55}$ Versnel (2011) 317.

${ }^{56}(2013) 6$.
} 
of structuralism'. Where once 'belief' was a dirty word in the study of Greek religion, ${ }^{57}$ dismissed as 'epiphenomenological noise', ${ }^{58}$ or shrunk to a small sample of texts, ${ }^{59}$ there now seems no lack of books forthcoming on belief, theology, even faith. ${ }^{60}$ 'It used to be said that Greek religion was about doing rather than believing', Jim remarks almost casually; if we fail to accommodate religious mentalities within our overall picture indeed, she adds more trenchantly, 'much of Greek religion is incomprehensible'. ${ }^{61}$ The very directness of her manner, treading so lightly over such fought-over terrain (by contrast, say, to Versnel's splendidly fiery rebuttal of the denial of 'belief') suggests that for a new generation a shift has already taken place. 'First offerings' - the giving of a portion of 'each harvest, each meal, or each military victory' to the gods- had, in the argument of her compelling, consummately researched monograph, both worldly purposes (competition, display) and unworldly (honouring the gods, averting evil). ${ }^{62}$

Where polis-centred approaches had a tendency to '[work] on the assumption that all members of ancient societies were in principle equally religious', ${ }^{63}$ there is a new-found emphasis on the possibility of individual variation within a religious repertoire. This is indeed the explicit focus of two edited collections, both emerging from the Erfurt powerhouse in the study of ancient religion: Veit Rosenberger's on divination, subtitled 'Options and the Individual', and Jörg Rüpke's on the individual in Mediterranean religion more broadly. ${ }^{64}$ In two of the most stimulating pieces in these volumes, Esther Eidinow examines the different Greek conception of the self (one defined in relational terms); while Lisa Maurizio envisages the individual client in divination as possessing an authority 'to suture the divine word and human world in a way that comported with his desires and needs', questioning whether religious individualism was absent in the Greek world. ${ }^{65}$

\footnotetext{
${ }^{57}$ Or so it was claimed (by me) on the jacket blurb of Harrison 2000.

${ }^{58}$ Gagné (2013) 6.

${ }^{59}$ Price (1999) 6, 126; see here Bremmer's refreshing observation, (2010a) 33 ('Although the major handbooks do pay attention to the religious role of poets and philosophers, one never gets the feeling that this is seen as an important part of the history of Greek religion').

${ }^{60}$ Anderson (forthcoming); Eidinow, Kindt \& Osborne (forthcoming); a further book on faith planned by Teresa Morgan and Barbara Kowalzig has now stalled.

${ }^{61} \operatorname{Jim}(2014)$ 21-2; cf. 58.

${ }^{62} \operatorname{Jim}(2014)$ 274, 276-7.

${ }^{63}$ Rüpke (2013) 3; cf. Price (1999) 108, minimizing individual choice ('Religious involvement ... generally resulted not from individual choices but from social expectations').

${ }^{64}$ See e.g. Rüpke's observations, in Rosenberger (2013) 14. The emphasis on the individual is one carried over into both Rüpke's (2014) and Rosenberger's (2012) introductory volumes (very different in character); see also Rüpke and Spickermann (2012) focussing on texts

${ }^{65}$ In Rosenberger (2013) 21-39 (this develops a strong theme of Eidinow (2007), esp. ch. 3), 75-6.
} 
There are also suggestions of a similar loosely cognitive (or, more broadly, experiential ${ }^{66}$ ) perspective across many of the books under review, even if all the authors are not yet giddy with 'shared enthusiasm'. Where the examination of an individual's state of mind was once thought inappropriate, ${ }^{67}$ individual perspectives are now speculatively reconstructed. Julia Kindt tiptoes around the potential value of cognitive approaches (certainly still only partially proven within the study of ancient religion ${ }^{68}$ ), concerned that 'while they may explain the neurological foundations of all religions rather well, what they can contribute to our understanding of a particular religious culture ... is much more difficult to assess. ${ }^{69}$ In one of the finest passages of her book, however, she imagines the experience of a hypothetical individual wending his or her way through the sanctuary at Olympia. As the statuary gazes back on you, 'any walk through the sanctuary' has the potential to turn into 'an ongoing engagement with a multitude of stories, identities and events, linked up in ever-new combinations and associations'; the dedications 'enacted the possible ways in which the Games could change an athlete's life', your life, as well as allowing you to look back across time at the 'the materialised image of a commonly inhabited past'. ${ }^{70}$ Irene Polinskaya likewise, despite an approach that is in general much more functionalist in flavour, finds herself - in parallel to Versnel ${ }^{71}$ - speculating on the mental processes of an individual worshipper in asking whether: ${ }^{72}$

\footnotetext{
${ }^{66}$ See e.g. Rüpke's observations, (2013) 20-22.

${ }^{67}$ See e.g. Osborne (1994) 144 ('What mattered was the performance of cult acts, not the state of mind of the actor').

${ }^{68}$ Studies that have used cognitive approaches fruitfully include Ustinova 2009, and a number of contributions to Anderson (forthcoming).

${ }^{69}$ Kindt (2012) 44. Generalising conclusions might in fact be usefully tested on the basis of evidence from a wider range of cultures and contexts, but the innate factors in human culture, as Dan Sperber pointed out long ago, 'do not determine cultural variations but only cultural variability', 1975: x (cf. pp. 136-7). Cf. very slight touching on cognitive approaches in Rüpke's survey of approaches to divination in Rosenberger (2013), 12.

${ }^{70}$ Kindt (2012) 134, 130, 153.

${ }^{71}$ But with different outcome: cf. Versnel (2011) 434 ('A Greek who is in dire trouble - desires the restoration of an eye, wishes to be rescued from a seething sea, is starving and craves food, cries out to save a child that is mortally ill - may and usually does pray to a god of his or her preference. To a large extent that choice is arbitrary and the addressee may just as well be a great soter-god as the unpretentious hero round the corner. However, from now on the adorant's full attention is focused on this god in whom he puts all his hopes and upon whom he makes himself entirely dependent. At this moment that god is the only one who can help while other gods temporarily disappear from sight. Such a prayer of a high grade of intensity, then, is a henotheistic moment in a polytheistic religion'); see also Versnel (2011) 59 on the identity of gods, citing Pl. Phlb. 12c ('in the matter of names of gods, my fear is beyond human measure, nothing indeed makes me so afraid').

"2 Polinskaya (2013) 88.
} 
a person choosing to use a particular ritual or to approach one particular deity out of the available multitude, could ever do so while closing one's eyes to the existence of other deities. Would a worshipper need only keep in mind a proper course of interaction with a deity of his choice, or also worry about negotiating his attention to other deities at that moment?

In a number of areas, however, the implications of this shift in interests, from the 'traditional focus on ritual practice to the mental and psychological', ${ }^{73}$ have inevitably not been fully realized. Our hesitancy over terminology, first, reveals a broader uncertainty about the object of study. What do we mean, for example, by 'theology'? Kindt suggests we should move beyond envisaging theology as a 'systematic and explicitly formulated body of knowledge', questioning whether this conception is 'too narrowly grounded in Christianity to allow us to conceive of other forms of theological reflection in other religious traditions'. We should think of theology not 'of course, ... in the form of a definite and binding formula as in revealed religions ..., but as a form of theological speculation that evolved in narrative and episodic form, and was descriptive rather than prescriptive'. ${ }^{74}$ In practice, however, we might identify a range of types or levels of Greek theology: the self-conscious development of a free-standing system of religious thought (notably, for example, by some Presocratics ${ }^{75}$ ); narratives with at least implicitly prescriptive morals, miracle stories for example with the implicit recommendation that one should be mindful of the gods; ${ }^{76}$ the 'usable stories' or 'negotiable project-narratives' of divination which helped the individual to model the uncertain choices he or she faced; ${ }^{77}$ as well as a chaotic accumulation of other implicit or 'intuitive' beliefs. How, we might wonder, can we meaningfully bracket all these phenomena under any single heading, theology or belief?

Conversely, in contrasting a loose (Greek) narrative theology with the 'definite and binding formula' of Christianity and other prophetic or revealed religions, are we again giving too much weight to these religions' distinct (internal) perspective? It is in this harder sense of 'theology', it seems, that Robert Parker, on the basis of the prevalent Greek principle of divine unknowability, ${ }^{78}$ describes Greek religion precisely as untheological. 'One needed to know how to worship the gods in ways pleasing to

\footnotetext{
${ }^{73} \operatorname{Jim}(2014) 3$.

${ }^{74}$ Kindt (2012) 188, 193.

${ }^{75}$ See here e.g. the work of Tor, e.g. forthcoming a and $b$.

${ }^{76}$ Harrison (2000); see also Kindt (2012) ch. 2 for the story of Parmeniscus.

"Gordon in Rosenberger (2013) 119-20 (in the context of astrology).

${ }^{78}$ For which see e.g. (with different formulations and emphases): Gould (1985), Rudhardt (1992) 88, 103-6, Sourvinou-Inwood (2000a) 20, Harrison (2000) 178-81, 189-92, Versnel (2011) 49-51.
} 
them; one did not need to know precisely what these gods were like. The ability to carry on without such knowledge was a defining characteristic of this untheological religion. ${ }^{79}$ Clearly, Greek religion is without the developed, systematic theological exploration of medieval Europe, and yet Christian theology also, by its very essence, is predicated on an uncertainty about the object of its study. In the apophatic tradition in Christian thought, for example, 'the impossibility of the worshipper's task' was reflected in what has been described as a 'liturgical stammer'. ${ }^{80}$ In drawing a distinction between the (weak) hopes that Greek religion offered of the afterlife and the 'firm beliefs' imposed by Christianity, ${ }^{81}$ are we reading protestations of orthodoxy too literally? A strong emphasis in recent cognitive studies of religion has been on the gulf that exists in 'credal' religions between, on the one hand, formal doctrinal positions and, on the other, the beliefs manifested in everyday 'online' contexts. Pascal Boyer and others have written of the 'tragedy of the theologian', that 'there always seem to be some nonstandard beliefs and practices left sticking out', and the inability of those charged with doctrinal consistency to assert any meaningful control. ${ }^{82}$ (Can any religion ever hope to impose firm beliefs?) In this broader context, issues of authority and control are arguably less important, and the need for the polis as a make-weight for the absence of the structures of modern institutionalised religion, as an 'alternative concept of religious administration and signification', ${ }^{83}$ less pressing.

When it comes to the question-marks over the term 'belief', there seem to be three prevailing options. The first, following Versnel and others, is to distinguish between a high-intensity 'credal' belief and a low-intensity definition, an everyday sense devoid of Christian overtones. ${ }^{84}$ (We may wonder further whether Christianity is in practice as devotional, or 'high-intensity' as even this contrast supposes, or whether 'reciting the Apostle's Creed' is not 'rather an act of ritual than of conscious belief'? ${ }^{85}$ ) A second response is to deem the term irredeemably Christian in its associations, and so to prefer another. So, for example, Gagné prefers to discuss ancestral fault as a cultural concept. ('The vast semantic range of the word "belief", its fundamental ties to conviction and devotion and so many other heirs of the Christian credo in the Western imagination make it difficult

\footnotetext{
${ }^{79}$ Parker (2011) 15.

so Pickstock (1997) 61.

${ }^{81}$ Parker (2005) 368.

${ }^{82}$ Boyer (2001) 281; cf. Tremlin (2006) 92, 96, 161, 163, 171 and, in Roman context, King 2003: 282.

${ }^{83}$ Kindt (2012) 34.

${ }^{84}$ Versnel (2011) 547-8. Cf. the (tangled) formulation of Larson, (2013) 150: "' belief," understood as intellectual assent to the proposition that the gods exist and take an interest in human affairs, was taken for granted as part of the worldview, just as we take for granted that people know the world is not flat.'

${ }^{85}$ Versnel (2011) 552; for the performativity of the Creed, see (from a different perspective) Pickstock (1994).
} 
to limit the connotations of the term... ${ }^{86}$ ). The third (overlapping) option is, in effect, to evade issues of terminology. So, for example, Jim sets out straightforwardly to ask 'what their [the Greeks'] behaviour [in dedicating first fruits to the gods] tells us about their religious beliefs, mentalities and presuppositions' ${ }^{87}$

The existence of some such psychological domain within Greek religion - call it belief for shorthand - is now arguably so widely acknowledged that it is tempting to imagine that it is a non-issue. Of course there was such a thing as belief. 'One worships the gods', according to Parker, 'because, experience shows, benefit derives from doing so. The gods are there. At this very basic level there is indeed belief, a belief very generally shared, or at least feigned....' ${ }^{88}$ Belief, however, in such formulations, often seems to be envisaged in restricted terms as a kind of penumbra to ritual action (ritual, by contrast, operates as a kind of trump card, in Denis Feeney's image ${ }^{89}$ ). There is a temptation, moreover, to envisage belief as secondary, as somehow less substantial than ritual action. Is Greek religion, Robert Parker wonders, 'a matter of things done at or near an altar' or 'the sum of the stories, speculations, and appeals'? 'One way of mediating' between these two views 'is to argue that, though beliefs were held, only acts were subject to appeal'. ${ }^{90}$ But why should we be concerned with primacy? Parker's work must stand both as the richest, most nuanced elaboration of the polis-religion model (in his two great volumes on Athenian religion) and (through his series of essays on 'literary religion') as amongst the very subtlest explorations of Greek theology. It also, however, reveals a certain awkwardness on the boundaries between 'literary' and 'real' religion; ${ }^{91}$ it is striking, in particular, that these two strands of his work rarely coincide in the same piece of writing. ${ }^{92}$ So, in his On Greek Religion, he allows that 'there is no reason to exclude' topics such as fate or theodicy from the study of Greek religion - indeed goes further in saying that to omit such issues from consideration is to

\footnotetext{
${ }^{86}$ Gagné (2013) 6-8; cf. Parker (2011) 2 ('what we might be tempted to term "beliefs" about the gods').

${ }_{87} \mathrm{Jim}(2014) 2$.

${ }^{88}$ Parker (2011) 32, then questioning whether this 'foundational belief' should be seen instead as certainty or knowledge; cf. Parker (2011) 2 ('Yet surely even a ritual is performed in the belief that there was some purpose in doing it'), his similar formulation, (1996) 1 , and his sensible cautions on instrumental views of ritual (2005) 157-8); for Roman religion, Linder and Scheid (1993): 53-4. .

${ }^{89}$ Feeney (1998) 10.

${ }^{90}$ Parker (2011) 2; cf. pp. 33-4.

${ }^{91}$ See e.g. his cautious breaking down of the distinction, Parker (1997) 148, with my comments, (2007) 374.

${ }^{92}$ Athenian religion: Parker (1996). 'Literary religion': Parker (1997), (1999), (2004). 'Theological' passages in Parker (2005): e.g. 101, 104, 146-7, 363-5.
} 
trivialize the Greeks - and yet finds it impossible to 'bring the two things together within a single field of argument'. ${ }^{93}$

Works such as those of Jim, Versnel and Kindt point the way here, towards realizing a more inclusive definition of religion, one which integrates these two facets. They also point the way towards moving from debating the existence of 'belief' or theology in the Greek world, whether as a Greek concept or as an object of study (a sterile debate now, in the light of Versnel's fourth appendix) to detailing plural beliefs, from the systematically developed explorations of philosophers to more passing, intuitive beliefs, in more detail. The reason that terminology still matters is that we need to differentiate between different forms of belief - between 'database' or 'intuitive' beliefs, on the one hand, 'reflective' beliefs on the other - or between the different possible meanings of theology, in order effectively to chart Greeks beliefs and their interrelationships. ${ }^{94}$

There is a new-found desire, moreover - reflected across the books under review - to explore the manner in which religious beliefs are articulated: through language, cult and image. For Kindt, for example (whose projected book on religious storytelling promises much), stories are interesting for their narrative shaping, not in spite of it. Likewise, Versnel focusses closely on the ambiguities and intricacies of religious language, the slippage between literal and figurative usages, seeing the phrase 'as if' for example (Don't try to find out if he [god] is or not, but worship him as if he is') as offering 'perhaps the most productive and promising strategy in religion'. ${ }^{95}$ Emily Kearns (in her consummate account of Greek religion in the Cambridge History) writes of a 'grammar of sacrifice', 96 all the nonverbal ways through which men and women approach the divine. And Kindt builds thought-provokingly on the work of Jas Elsner and others on religious visuality to show how the journey of Parmeniscus to Delos (recounted by Athenaeus) reveals the alternation of a religious (but not ritual-

\footnotetext{
${ }_{93}$ Parker (2011) xii: 'it is implausible to deny that "ordinary Greeks" were interested in the problems of divine justice and fate and the rest, even if such concern is mostly revealed to us through literature. Nor does the comparative fixity of cult rules, as opposed to the ebb and flow of competing opinion about abstract topics, make the former more real than the latter. We trivialize the Greeks if we do not engage with their thought on these issues. But it is not easy to bring the two things together within a single field of argument. The concentration in this book on cult practice is based not on a judgement about what might constitute "real" religion, but more mundanely on the wish to do one thing at a time.' Cf. his similar remarks on the exclusion of comparativism, (2005) 2 ('one must do one thing at a time').

${ }^{94}$ See further Harrison (forthcoming).

${ }_{95}$ Versnel (2011) 279, quotation (from the New comedian, Philemon) at p. 473; cf. p. 471 for 'honest pretence', or his remark (p. 18) that the academic author likewise is "bound to "do as if" he believes in (the results) of what he is doing'. For the slippage between literal and figurative, see further Harrison (forthcoming); contrast the emphasis of Parker, e.g. (2005) 363, (2011) 32.

${ }^{96}$ In Salzman, Sweeney and Adler (2013) i. 293.
} 
centred) visuality with a more worldly way of viewing, how the story in effect models both superficial and more deeply intuitive ways of viewing the same image. ${ }^{97}$ Implicit here is a recommendation of the necessary frame of mind for approaching the divinity - and also of divinity's inaccessibility. By contrast to gleaming cult statues with their 'surplus of splendour' and bodily perfection', other semi-iconic or aniconic images reflect, no less than literary texts, the uncertainty principle (or the principle of unknowability) which underpins much of Greek religion. ${ }^{98}$

Another central concern of a number of books under review is the relationship of local and panhellenic, microsmic and macrocosmic, aspects in Greek religion: in other words, the character of Greek polytheism. Polinskaya's history of Aeginetan religion seeks to find a middle path, '[steering] away both from the pitfalls of the panhellenic model and from the limitations of the polis-centred model'. ${ }^{99}$ Previous studies, Polinskaya maintains, either focussed 'on isolated specific deities or divine personalities, or on the correlation of deities either in a poetic (e.g., Homeric) world or in an abstract composite pantheon'. In particular the polis-model was underdeveloped both in failing to accommodate other forms of (more ad hoc) organisation - so Polinskaya prefers the term community to polis, with Michael Jameson ${ }^{100}$ - and for failing to extend its picture of the 'systemic' nature of local religion. It is not clear how clearly different is the alternative course proposed. Polinskaya's declared intention to focus on 'the work of "many gods" within a local cultic system" ${ }^{101}$ is one with which Sourvinou-Inwood, for example, would surely have been intensely sympathetic. Polinskaya arguably also de-emphasises the 'macrocosmic' level in Greek religion by supposing that it is dependent upon some single federal or centralised form of political and social organisation. ${ }^{102}$ In addition to the value of her detailed exploration of the Aeginetan evidence, however, she usefully warns against assuming stark polarities between local and panhellenic, envisaging rather a continuum within an individual's

\footnotetext{
${ }^{97}$ E.g. Elsner 2007.

${ }^{98}$ Kindt (2012) 46; for unknowability, see above n. 77.

${ }^{99}$ Polinskaya (2013) 23.

100 Citing Jameson (1997) 172-3.

101 Polinskaya (2013) 23.

102 Polinskaya (2013) 33 ('The macrocosmic level, which often relies upon the view of ancient Greeks as a social unity has no basis in social reality, as Greece never achieved the status of a federal or any kind of centralized political state, and hence the Greeks in practical terms never constituted a single political community'), 42 ('a system at the panhellenic level can only be envisioned as a virtual reality, a construct, as it will always lack a corresponding social structure') .
} 
religious experience, 'in which there was also room for regional, ethnic, amphictyonic, and other forms of involvement'. ${ }^{103}$

How, though, are we to understand the relationship between different local cults of the same god - a problem that again goes back to a classic discussion of Sourvinou-Inwood ${ }^{104}$-, between the Pan worshipped in one community and in another? Cult epithets have been seen traditionally as representing different local 'manifestations' of a single divinity, so assuming an underpinning structure. ${ }^{105}$ As Parker explores, there has been a tendency in general handbooks to offer 'unifying account[s] of a particular god's functions', eliding overlaps and confusions. ${ }^{106}$ In place of such systematizing approaches, or of a structuralist model postulated on a 'large database of theological knowledge in the mind of every Greek, ... a willingness to be bound by its implicit rules', ${ }^{107}$ newer formulations try in different ways to encapsulate the inconsistent complexity of the Greeks' religious world, 'the incredible, yet undeniable potentials of living religion'. ${ }^{108}$ For Kearns, in a nicely overarching formulation, Greek religion combines two tendencies, which held each other in check, the centripetal and centrifugal. ${ }^{109}$ For Parker, the gods are 'like a concertina, that can be expanded or contracted'. ${ }^{110}$ At the same time, however, he acknowledges that the 'attempt to confer logical coherence on polytheism is a hopeless enterprise'. ${ }^{111}$

Versnel takes this position further, rooting the logical incoherence of Greek representations of the divine in the nature of human cognition. 'The gods who were worshipped in the different poleis were', for Sourvinou-Inwood, 'of course, perceived to be the same gods. ${ }^{\text {,112 }}$ But were they? Just as the Virgin Mary might be addressed by the same set of names everywhere and yet locals be convinced that the Maria of this particular church or parish, with her particular surname is a special local Maria with very special qualities, and as such different from other Marias', ${ }^{113}$ so for the Greeks also, as Versnel highlights through exhaustive presentation of evidence, 'Gods bearing the same name with

103 Polinskaya (2013) 492-3; cf. Eidinow's critique, (2011) 32, of binary categorisations in polisreligion, or the emphasis on a range of levels of religious activity in Jim, (2014) 276.

104 Sourvinou-Inwood (1978).

105 Versnel (2011) 62.

106 Parker (2011) 86; cf. Kindt's discussion of Burkert's approach, 'driven by the overall aim of bringing single local aspects of the Greek pantheon together into one more or less coherent narrative...', (2012) 25-6.

107 2011: 94; see also Parker (2005) 387-95.

108 Versnel (2011) 523.

109 Kearns in Salzman, Sweeney and Adler (2013) i. 284.

110 Parker (2011) 87.

111 Parker (2011) 98.

112 Sourvinou-Inwood (2000a) 18.

113 Versnel (2011) 523. 
different epithets were and were not one and the same, depending on their momentary registrations in the believer's various layers of perception.' ${ }^{114}$ This seeming contradiction is only one, moreover, of a series of paradoxes inherent in Greek religious experience. A god may be both omnipotent and limited in scope, with Hermes the 'least godly' of them all. ${ }^{115}$ And the Greeks were capable of tolerating several diverse explanations of the same event, for example of the death of the Lydian Croesus. ${ }^{116}$ If we find difficulty with this level of inconsistency, that is our problem, not the Greeks'. The villains of Versnel's magnificent, sprawling book, are those modern scholars, the hermeneuticians with their 'strain towards congruence', ${ }^{117}$ who in their desire to save their author from imagined charges of obscurantism or incoherence, to tidy up their authors' thought, have elided the evidence of such complexity.

Chaos or system, then $?^{118}$ For Polinskaya, the interconnections in Greek polytheism pull it back from the precipice. For Versnel, as for Parker, chaos has its uses. 'Incoherence made it all the more flexible a tool for coping with the diversity of experience'. ${ }^{119}$ 'One might value', writes Versnel, 'this versatile, multifaceted and multiple concatenation of explanatory devices in matters of theology and philosophy of life as an honest, challenging and perhaps even aesthetically satisfying device to live by'. ${ }^{120}$ Inevitably, however, there will always be scholars uncomfortable at the failure to find an underlying order. Kindt advocates that we give space to 'the fault-lines between contradictory religious beliefs and practices, and the internal frictions, inconsistencies and tensions springing from them', warns against explaining away inconsistencies, and yet declares that the study of inconsistency ${ }^{121}$

is fruitful only when it is itself 'embedded' ... in a wider framework of perspectives exploring the nature of different - even divergent - belief systems within the wider, general culture. The simple presentation of inconsistencies cannot be heuristically satisfying, as we cannot be sure that what we are dealing with is more than just our failure to see coherence. The only way to distinguish, to some extent at least, our own failure to understand from true plurality of belief is to place such dissonances within a larger framework of cultural contestation.

114 Versnel (2011) 82, cf. pp. 100, 517, Polinskaya (2013) 492, 497, Kearns in Salzman, Sweeney and Adler (2013) i. 281-3.

115 Versnel (2011) 436.

116 Explanations classified at Versnel (2011) 187; cf. 213.

117 Versnel (2011) 190.

118 Polinskaya (2013) 537.

119 Parker (2011) 98; cf. (2005) 444-5.

120 Versnel (2011) 213; cf. p. 162.

121 Kindt (2012) 20, 24, 26. 
'So maybe nothing makes sense' as Frits Naerebout has remarked (half hopefully, half in lament?), 'but anyhow, everything is made sense of'. ${ }^{122}$

What next in Greek religion then? Though the critique of polis religion may be 'symptomatic of a possible paradigm shift in studies of Greek religion', as Polinskaya observes, 'it is not clear where it will take us'. Just as others have endorsed cognitive approaches as one fruitful route (in many cases uneasily), so Polinskaya points to the network model (proposed by Eidinow) or to (Kindt's adoption of) 'thin coherence' as possible directions, but in neither case one that would supplant the polis as focus. ${ }^{123}$ Where there is apparent consensus at least is in the need for a diversity of approach. Polinskaya reviews a whole range of paradigms - the city-countryside dichotomy or chthonian-Olympian, biological, psychoanalytic - before concluding, soundly but underwhelmingly, that we should stay alert to the pervasiveness of all existing paradigms and 'not allow the pressure of paradigms to obscure or distort and over-ride the concreteness and peculiarity of local data'. ${ }^{124}$ For Julia Kindt, likewise, 'there is no single approach that either can or should supersede the polis model'. ${ }^{125}$ The polis-religion model explains some aspects of Greek religious experience and not others. The polis may be besieged, but there is no appetite to sack it and build anything else in its place.

We need then to take a catholic approach to the kaleidoscopic ${ }^{126}$ reality of Greek religion. If 'magic differs from religion as weeds differ from flowers, merely by negative social evaluation', ${ }^{127}$ then both should be envisaged as falling within the messy borders of Greek religion. As Kindt argues, rather than our confusing evaluative concepts within a religion with external, descriptive categories, any discourse on the legitimacy of a particular practice should be seen instead as part of a wider civic

122 Naerebout (1997) 396 n. 946; cf. Needham 1972: 244: 'I am not saying that human life is senseless, but that we cannot make sense of it'.

${ }_{123}$ Polinskaya (2013) 25 and n. 84.

${ }_{124}$ Polinskaya (2013) 69.

125 Kindt (2012) 34.

126 The analogy is Versnel's, (2011) 10: 'One-sided or universalist theories in the field of Greek theology by their very nature tend to be misleading since they illuminate only part of a complex and kaleidoscopic reality, which is neither fully transparent/structured nor entirely chaotic'.

127 Parker 2005: 122, with critique of Eidinow (2011) 21-2 for his merging of ancient and modern associations. 
'theology'. ${ }^{128}$ Arguably also, we need to be less concerned with labelling and categorising (so, in the neat illustration of Gagné: 'this is Orphic; this is Bacchic; that is clearly Sabaziac; this, on the other hand, is Orphico-Dionysiac'), move beyond the paralysing fixation on the Christianising association of particular terminology, ${ }^{129}$ and to develop the renewed focus on the history of scholarship ${ }^{130}$ - in awareness that there are no neutral explanatory models, and that our own attempts to impose order say as much about our own preconceptions and anxieties. ${ }^{131}$ (What does it say indeed that we are now reinstating the gods, or seeing disorder and dissonance where before we found structure?)

Above all, perhaps, we need to avoid the dogmatism that has sometimes beset the subject, and to avoid seeing any single aspect as primary or exclusive. ${ }^{132}$ Summary accounts tend to throw up crisp formulations of the nature of Greek religion - or of religion in general : that it is above all, for example, a medium of communication between men and gods, or that it forms a means for the explanation of events, the construction of identity, or to cope with life's vicissitudes - for the individual in dire trouble, who 'wishes to be rescued from a seething sea, is starving and craves food, cries out to save a child that is mortally ill'. ${ }^{133}$ It is all these things and more: Parker, for example, has put a healthy emphasis also on the worldly pleasures of Greek religion, its 'relaxed blend of piety with evident relish for the simpler good things of this world'. ${ }^{134}$ It can also be seen, with equal legitimacy, from different vantage points: as abstracted and as physically grounded in specific locations, in city and countryside; ${ }^{135}$ as personal and public (in practice, hard to disentangle $\left.{ }^{136}\right)$; individual, local, panhellenic, universal, and everything in between. As the books under review illustrate, religion is central, for example, to the construction of a range of different identities: ${ }^{137}$ to articulating what it means to be Aeginetan, ${ }^{138}$ but equally to expressing, through a dedication, the pride of a fuller or a washerwoman in their trade. ${ }^{139}$

${ }_{128}$ Kindt (2012) 108, 113; cf. observations of Rüpke (2013) 6.

${ }_{129}$ See also now Naiden's suggestion of offering instead of sacrifice, (2013) 330, with the response of Carbon (2013) 388.

${ }_{130}$ E.g. Parker (2011), Bremmer (2010b), Konaris (2012), Faraone and Naiden (2012), Gagné (2013), Naiden (2013).

${ }_{131}$ Cf. Woolf (1997) 71-2.

${ }_{132}$ See e.g. Veyne (2000) for the impossibility of any single interpretation of sacrifice.

133 Versnel (2011) 434.

134 (2011) 201; cf. (2005) 45.

${ }_{135}$ See e.g. Parker (2005) ch. 3, (2011) x-xi, Buxton (1994), Ustinova (2009).

${ }_{136}$ See the observations of Parker (2005) 44, Jim (2014) 276, and now the thoughtful analysis of Kindt (2015).

137 Kindt (2012) 125.

${ }_{138}$ Polinskaya (2013) 549; cf. Parker (2005) 444 on Athena.

$139 \mathrm{Jim}$ (2014) 174-5. 
Indeed, as Theodora Jim observes sensitively in this last context, this everyday work is transformed, its value 'redefined in a dedicatory context'. Here, in this confident dedication of one's own trade, as if it were in its own right an act of piety, ${ }^{140}$ or elsewhere, for example, in the anxious open-ended individual perspective towards worship offered up by so much recent work, we are perhaps fulfilling Jean Rudhardt's ambition to go beyond the structures of religion and to enter into the mind of the devotee, 'to gain access to the subjective experience which is at least partially conditioned by the structures and expresses itself through these. ${ }^{141}$ This was a conception of Greek religion that might seem to have been long marooned. ${ }^{142}$ By contrast, it has been too easy perhaps especially when working within a framework which envisages religion as a matter of social realities to envisage the Greeks as, at some base level, seeing the world in the same terms, making decisions on the same 'rational' basis, as ourselves. ${ }^{143}$ For Robert Parker's Greeks, rain was just rain - unless it declined to fall: ${ }^{144}$

if every shower of rain comes from Zeus ... then direct contact with divine power is an everyday experience. It surely will not have felt like that, even for the pious: rain for them was rain, part of normality, as it is for us, not an epiphany. But when rain declined to fall, it could be prayed for; thunderbolts were embodiments of "Zeus who descends", storms could be caused by human pollution, winds could be summoned or averted by sacrifice.

Some of the new emphases in the study of (Greek) religion - for example the focus on visuality, on language or narrative - open up the possibility that 'religion' for the Greeks was embedded not just in society but in the cognitive construction of reality - 'the underpinning, the emotional and cognitive foundation, of the whole of communal life'. ${ }^{145}$

${ }_{140}$ Cf. du Boulay (2009) 418 ('times of labour are enfolded in the timeless'), and (more broadly) for a Christian theology of work, Hughes (2007).

141 Rudhardt (1981) 10. In addition to the books under review, see esp. Eidinow 2007, revealing (on the basis of curse tablets and oracles) 'ordinary Greek men and women from every walk of life, dealing with everyday fears and uncertainty, in an atmosphere that was sometimes gripped by gossip, prickling with accusations' (p. 237). It is perhaps significant that the work of E.R. Dodds, esp. (1951), is at this point being honoured in a forthcoming OUP collection.

142 For Rudhardt's intellectual formation and the unusually detached context (in a sanatorium) in which his most substantial work (1992, originally published 1958) was completed, see the introductory material, by Philippe Borgeaud and Vinciane Pirenne-Delforge, to Rudhardt (2006).

${ }_{143}$ See e.g. Price's discussion, (1999) 74, of the wooden wall oracle; for the difficult concept of rationality, cf. (appropriately obscure) Harrison (2006).

144 Parker (2011) 3.

145 Parker (2005) 452. 
This could be seen in a relatively passive, background sense - 'easy to live with, like a comfortable old coat'; 'in the background of awareness' ${ }^{146}$ - or it could be transformational. For Versnel, in a lauded article, the individual Greek had to reckon with the possibility that anyone they met might be a god in disguise. ${ }^{147}$ If work can be more than just work, and if the continuation of agricultural plenty (or any other aspect of good fortune), were indeed seen as depending on a proper pattern of propitiation of divinity, then rain too could surely have been more than just rain, and divine intervention - far from being a rarity ${ }^{148}$ - might have been constant and patent. 'Water from a tap is a convenience', as Juliet du Boulay expresses it in her extraordinary account of the religious world-view of a Greek Orthodox village, 'but drunk from a hillside or carried from the spring to the table it is a miracle'. 'At the same time as they are relating to the world about them they [the people of the village of Ambeli] are walking through a sacred drama'. ${ }^{149}$ For the ordinary Greek of our period, the everyday may not have mapped in the same way onto a single overarching cosmic liturgy, but it may nonetheless have been richly embroidered with the potential, the threat and the hope, of the divine.

\section{BIBLIOGRAPHY}

Anderson, R. (forthcoming) Belief and its Alternatives in Greek and Roman Religion (Cambridge) Boulay, J. du (2009) Cosmos, Life and Liturgy in a Greek Orthodox Village (Limni, Evia)

Boyer, P. (2001) Religion Explained (New York)

Bremmer, J. (2010a) 'Manteis, magic, mysteries and mythography: messy margins of polis religion', Kernos 23, 13-35

Bremmer, J. (2010b) 'Introduction: the Greek Gods in the Twentieth Century', in Bremmer and Erskine (2012), 1-18

Bremmer, J. and A. Erskine (2012) (eds), The Gods of Ancient Greece (Edinburgh)

Burkert, W. (1995) 'Greek poleis and civic cults: some further thoughts', in M.H. Hansen and K.

Raaflaub (eds.) Studies in the Ancient Greek Polis (Stuttgart) 201-10

Buxton, R. (1994) Imaginary Greece. The Contexts of Mythology (Oxford)

146 Parker (2005) 453, 104.

147 Versnel (1987).

${ }_{148}$ Cf. Price (1999) 133: 'though the gods existed, only in exceptional circumstances would an individual be sure that one of them had intervened in his or her life'; we might choose to underline the emphasis here on certainty (surely anyway elusive).

149 Du Boulay (2009) 79, 101. 
Buxton, R. (2000) (ed.) Oxford Readings in Greek Religion (Oxford)

Carbon, J.-M. (2013) 'Ritual problems: offering and sacrificing', Kernos 26, 381-8.

Certeau, M. de (1984) The Practice of Everyday Life. Tr. By Steven F. Rendall (Berkeley)

Dodds, E.R. (1951) The Greeks and the Irrational (Berkeley CA)

Eidinow, E. (2007) Oracles, Curses and Risk among the ancient Greeks (Oxford).

Eidinow, E. (2011) 'Networks and narratives: a model for ancient Greek religion', Kernos 24, 9-38

Eidinow, E.., J. Kindt and R. Osborne (eds.) (forthcoming) Theologies of Ancient Greek Religion (Cambridge)

Elsner J. (2007), Roman Eyes. Visuality and Subjectivity in Art and Text (Princeton)

Erskine, A. (2010) 'Epilogue', in Bremmer and Erskine (2010) 505-10

Faraone, C.A. and F.S. Naiden (eds.) (2012) Greek and Roman Animal Sacrifice. Ancient Victoms, Modern Observers (Cambridge)

Feeney, D. (1998) Literature and Religion at Rome (Cambridge)

Georgoudi, S. (2010) 'Sacrificing to the gods: ancient evidence and modern interpretations', in Bremmer and Erskine (2010), 92-105

Gagné, R. (2013) Ancestral Fault in Ancient Greece (Cambridge) Garland, R. (1994) Religion and the Greeks (London)

Gough-Olaya, A. (2014) Personal Commitment and Academic Practice. An Anthropology of the Study of Ancient Religion (unpublished Liverpool PhD thesis)

Gould, J. (1985) 'On making sense of Greek religion', in P. Easterling and J.V. Muir (eds.) Greek Religion and Society (Cambridge), 1-33

Harrison, T. (2000) Divinity and History. The Religion of Herodotus (Oxford)

Harrison, T. (2006) 'Religion and the rationality of the Greek city', in S. Goldhill and R. Osborne (eds.)

Rethinking Revolutions in Ancient Greece (Cambridge) 124-40.

Harrison, T. (2007) 'Greek religion and literature', in D. Ogden (ed.) Blackwell Companion to Greek Religion (Oxford) 373-84

Harrison, T. (forthcoming) 'Towards a psychology of Greek religious belief', in Anderson (forthcoming) Henkelman, W. (2008) The Other Gods who Are. Studies in Elamite-Iranian Acculturation Based on the Persepolis Fortification Texts (Achaemenid History XIV: Leiden)

Hughes, J. (2007) The End of Work. Theological Critiques of Capitalism (Oxford).

Jameson, M.H. (1997) 'Religion in the Athenian democracy', in I. Morris and K. Raaflaub (eds.)

Democracy 2500? Questions and Challenges (Dubuque, IA), 171-95

Kindt, J. (2015) 'Personal religion: a productive category for the study of ancient Greek religion?', JHS 
King, C. (2003) 'The organisation of Roman religious beliefs', Classical Antiquity 22.2, 275-312

Konaris, M. (2010) 'The Greek gods in late nineteenth- and early twentieth-century German and British scholarship', in Bremmer and Erskine (2010), 483-503

Larson, J. (2013) 'Greece', in B.S. Spaeth (ed.) Cambridge Companion to Ancient Mediterranean Religions (Cambridge), 136-56Linder, M and Scheid, J. (1993) 'Quand croire c'est faire: le problem de la croyance dans la Rome ancienne', Archives de sciences sociales des religions 81, 47-62.

Maurizio, L. (1995) 'Anthropology and spirit possession', JHS 115, 69-86

Naerebout, F.G. (1997) Attractive Performances. Ancient Greek Dance: Three Preliminary Studies (Amsterdam)

Needham, R. (1972) Belief, Language and Experience (Oxford)

Osborne, R. (1994) 'Archaeology, the Salaminioi, and the politics of sacred space in archaic Attica', in S. Alcock and R. Osborne (eds.), Placing the Gods (Oxford, 1994), 143-60

Parker , R. (1985) 'Greek states and Greek oracles', in P.A. Cartledge and F.D. Harvey (eds.) Crux. Essays presented to Geoffrey de Ste Croix (Oxford) 289-326, reprinted in Buxton (2000), 76-108

Parker, R. (1996) Athenian Religion. A History (Oxford)

Parker, R. (1997) 'Gods cruel and kind: tragic and civic ideology', in C. Pelling (ed.) Greek Tragedy and the Historian (Oxford), 213-35

Parker, R. (1998) 'Pleasing thighs: reciprocity in Greek religion', in C. Gill, N. Postlethwaite, and R. Seaford (eds.) Reciprocity in Ancient Greece (Oxford), 105-25.

Parker, R. (1999) 'Through a glass darkly: Sophocles and the divine' in J. Griffin (ed.), Sophocles Revisited. Essays presented to Sir Hugh Lloyd-Jones (Oxford) 11-30

Parker, R. (2004) 'One Man's Piety: the Religious Dimension of the Anabasis', in R. Lane Fox (ed.) The Long March: Xenophon and the Ten Thousand (New Haven) 131-153

Parker, R. (2005) Polytheism and Society at Athens (Oxford)

Pickstock, C. (1994) 'Asyndeton: syntax and insanity. A study of the revision of the Nicene creed',

Modern Theology 10, 321-40

Pickstock, C. (1997). After Writing. On the Liturgical Consummation of Philosophy (Oxford)

Pirenne-Delforge, V., and F. Prescendi (eds.) 'Nourrir les dieux?' Sacrifice et representation du divin (Kernos suppl. 26) (Liège)

Price, S. (1984) Rituals and Power. The Roman Imperial Cult in Asia Minor (Cambridge)

Price, S. (1999) Religions of the Ancient Greeks (Cambridge).

Pulleyn, S. (1997) Prayer in Greek Religion (Oxford)

Rudhardt, J. (1981) Du mythe, de la religion grecque et de la comprehension d'autrui (Geneva) 
Rudhardt, J. (1992) Notions Fondamentales de la Pensée Religieuse et Actes Constitutifs du Culte dans la Grèce Classique (Paris, $1^{\text {st }}$ edn.: Geneva, 1958)

Rudhardt, J. (2006) Les dieux, le féminin, le pouvoir (Geneva)

Rüpke, J. (2013) 'Individualization and individuation as concepts for historical research', in J. Rüpke (ed.) The Individual in the Religions of the Ancient Mediterranean (Oxford) 3-38

Rüpke, J. (2014) Religion. Antiquity and its Legacy (London).

Rüpke, J. and W. Spickermann (eds.) (2012) Reflections on Religious Individuality. Greco-Roman and Judaeo-Christian Texts and Practices (Berlin)

Santangelo, F. (2013) Divination, Prediction and the End of the Roman Republic (Cambridge). Sourvinou-Inwood, C. (1978) 'Aphrodite and Persephone at Locri: a model for personality definitions in Greek religion', JHS 98, 101-21, revised in her (1991) Reading Greek Culture: Texts and Images, Rituals and Myths (Oxford), 147-88.

Sourvinou-Inwood, C. (2000a) 'What is Polis Religion?', in Buxton (2000), 13-37, first published in

O. Murray and S. Price (eds.) The Greek City from Homer to Alexander (Oxford, 1990) 295-322

Sourvinou-Inwood, C. (2000b) 'Further Aspects of Polis Religion', in Buxton (2000), 38-55, first

published in AION(Arch) 10 (1988), 259-274

Sperber, D. (1975) Rethinking Symbolism (Cambridge)

Tor, S. (forthcoming a) 'Heraclitus on Apollo's language and his own: contemplating oracles and philosophical inquiry', in Eidinow, Kindt and Osborne (eds.) (forthcoming)

Tor, S. (forthcoming b) 'Belief and practice in Xenophanes' criticism of traditional religion' in Anderson (ed.) (forthcoming)

Tremlin, T. (2006) Minds and Gods. The Cognitive Foundations of Religion (New York)

Ustinova, Y. (2009) Caves and the Ancient Greek Mind. Descending Underground in the Search for Ultimate Truth (Oxford)

Versnel, H.S. (1987) 'What did Ancient Man See When He Saw a God?', in D. van der Plas (ed.) Effigies Dei. Essays in the History of Religion (Leiden), 42-55

Versnel, H.S. (1990) Inconsistencies in Greek and Roman Religion (2 vols., Leiden)

Veyne, P. (2000) 'Inviter les dieux, sacrifier, banqueter: quelques nuances de la religiosité grécoromaine', Annales, 3-42

Vlassopoulos, K. (2007) Unthinking the Greek Polis. Ancient Greek History beyond Eurocentrism (Cambridge)

Whittaker, C.R. (1965) 'The Delphic oracle. Belief and behaviour in Ancient Greece - and Africa', HThR 58, 21-47 
Wiebe, D. (1979) 'The role of "belief' in the study of religion. A response to W.C. Smith', Numen 26, 234-49

Woolf, G.D. (1997) 'Polis-religion and its alternatives in the Roman provinces', in H. Cancik and J. Rüpke (eds.) Römische Reichsreligion und Provinzialreligion (Tübingen), 71-84

Zunino, M.L. (1997) Hiera Messeniaka. La storia religiosa della Messenia dall'età micenea all'età ellenistica (Udine) 